\title{
Petrology and geochemistry of Devono-Carboniferous volcanic rocks in Nova Scotia
}

\author{
J. Dostal, Department of Geology \\ Saint Mary's University, Halifax, N.S. Canada $B 3 H 3 C 3$ \\ J.D. Keppie, Nova Scotia Department of Mines and Energy \\ P.O. Box 1087, Halifax, N.S. Canada B3J $2 \times 1$ \\ C. Dupuy, Centre Geologique et Geophysique, U.S.T.L. \\ 34060 Montpellier Cedex, France
}

\begin{abstract}
The Devono-Carboniferous volcanic rocks of Nova Scotia include Middle Devonian basalts from the McAras Brook Formation in the northern Antigonish Highlands (Ballantynes Cove and McAras Brook areas), Middle Devonian and Carboniferous basalts and rhyolites of the Fountain Lake Group in the Cobequid Highlands and the Upper Devonian-Lower Carboniferous basalts and rhyolites of the Fisset Brook Formation in Cape Breton Island. The volcanic rocks were extruded upon the continental crust in an intraplate setting. The basalts are tholeitic except those from Ballantynes Cove which are alkaline. All these basalts could have been derived from a similar upper mantle source - garnet peridotite. Rhyolites were probably generated by crustal anatexis related to the ascending basaltic magma. The Devono-Carboniferous volcanism is probably connected with rifting along faults bounding the Magadalen pull-apart basin. In the Cobequid Highlands, the volcanism appears to be spatially and temporally associated with plutonism.

Les roches volcaniques Dévono-Carbonifères de la Nouvelle-Ecosse comprennent: les basaltes de la formation McAras Brook (Dévonien moyen) dans la partie nord des hautes-terres d'Antigonish (régions de Ballantynes Cove et de McAras Brook); les basaltes et les rhyolites du groupe Fountain Lake (Dévonien moyen et Carbonifère) des monts Cobequid; et les basaltes et rhyolites (Dévonien supérieur-Carbonifère inférieur) de la formation Fisset Brook su l'Ile du Cap-Breton. Les roches volcaniques furent répandues à la surface de la croûte continentale dans un contexte intraplaque. Les basaltes sont tous tholéiitiques à l'exception de ceux de Ballantynes Cove qui sont alcalins. Tous ces basaltes pourraient provenir d'une même source située dans la partie supérieure de manteau terrestre - péridotite à grenat. Les rhyolites résultent probablement de l'anatexie de 1a croûte associée à la montée du magma basaltique. Le volcanisme Dévono-Carbonifère est probablement relié à une fissuration le long des failles qui encadrent le bassin de déchirement des Madeleines. Dans les monts Cobequid, le volcanisme semble associé de façon spatio-temporelle au plutonisme.
\end{abstract}

[Tradult par le journal]

\section{INTRODUCTION}

The Devonian Acadian Orogeny is one of the more significant events in the Paleozoic history of the northern Appalachians. The effects of the Acadian Orogeny extend from the Atlantic seaboard some $500 \mathrm{~km}$ across the trend of the Appalachians and include various degrees of deformation and metamorphism and widespread plutonism. Devono-Carboniferous volcanic rocks are widely scattered along two belts through northern New Brunswick to north-centra1 Maine and from northeastern Massachusetts through coastal Maine to northern Nova Scotia (Ruitenberg et al. 1977, Osberg 1978, Keppie and Dostal 1980).

MARITIME SEDIMENTS AND ATLANTIC GEOLOGY 19, 59-71 (1983)
In Nova Scotia, volcanic rocks of Middle Devonian to Carboniferous age occur in the Cobequid Highlands, northern Antigonish Highlands and Cape Breton Island (Fig. 1). There is only a limited amount of information on these rocks (Keppie and Dostal 1980, Smith and MacDonald 1981, Blanchard 1982) although an understanding of their petrogenesis would contribute substantially to any tectonic model for later stages of the Acadian Orogeny. The purpose of this paper is to present some geochemical data on the Middle Devonian basalts from the McAras Brook Formation in the northern Antigonish Highlands (northern Nova Scotia, Fig. 1) and to compare these rocks to other volcanic suites from Nova Scotia containing mafic rocks (basalts) for which a Middle Devonian to Carboniferous age is well documented. 


\section{GEOLOGICAL SETTING}

The McAras Brook Formation (Williams 1914, Bell 1926, Boucot et al. 1974, Keppie et a1. 1978) crops out in a few small isolated areas around the periphery of the Antigonish Highlands (Fig. 1) and is well exposed only along the coast of Northumberland Strait. The type section (MAB) occurs near Knoydart Point, west of Arisaig (Fig. 1), where continental red conglomerates and sandstones with intercalated basalt flows lie unconformably upon sedimentary rocks of Late Silurian and Early Devonian age (Boucot et al. 1974, Keppie et al.1978). The McAras Brook Formation is, in turn, unconformably overlain by Late Visean sedimentary rocks (Keppie et al. 1978). The basalt flows vary in thickness from 4 to $18 \mathrm{~m}$ and the aggregate thickness of basalts is about $70 \mathrm{~m}$.
At Ballantynes Cove, near Cape George, the McAras Brook Formation is composed of red conglomerate and about $70 \mathrm{~m}$ of basalts in five flows, and is overlain by clastic sediments of Middle Devonian age. The basalt flows at Ballantynes Cove (BC) probably lie stratigraphica1ly above all those exposed in the type section (Keppie et al. 1978). Thus, the rocks in the type section of the McAras Brook Formation are probably also of early Middle Devonian or late Early Devonian age.

Similar basalt flows occur in the Cobequid Highlands (Donohoe and Wallace 1980) in the Fountain Lake Group (FLG) (Fig. 1) which consists mainly of volcanic rocks, predominantly rhyolites with minor basalts and interbedded clastic rocks. In the Eastern Cobequid Highlands, the sequence is up to $3,000 \mathrm{~m}$

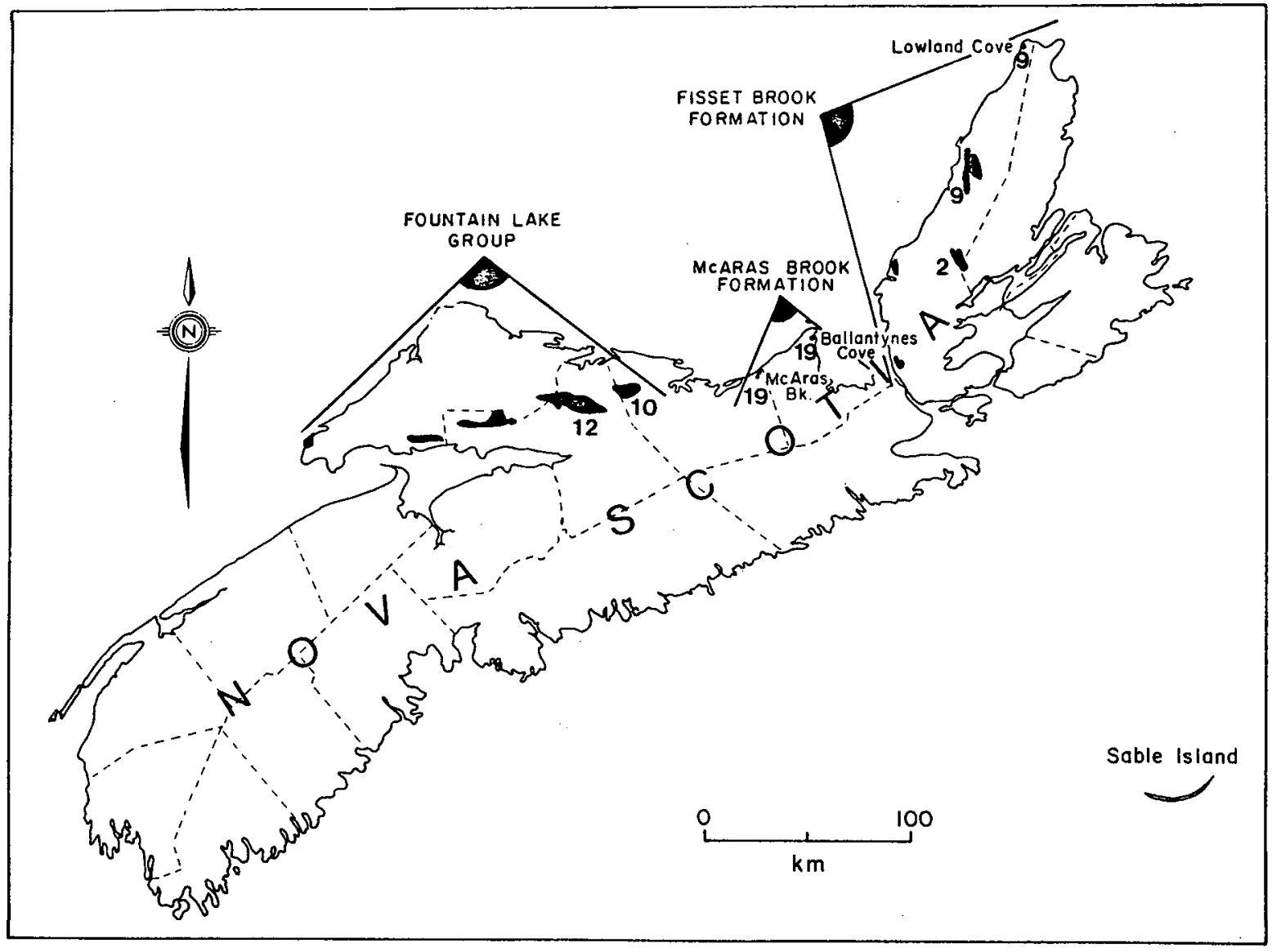

F1g. 1 - Map showing the distribution of Devono-Carboniferous volcanic rocks in Nova Scotia and indicating numbers of the samples from each locality. 
thick. The FLG has been inferred to be Middle Devonian in age (Donohoe and Wallace 1982). However, Cormier (1982) has recently obtained two different $\mathrm{Rb} /$ $\mathrm{Sr}$ isochron ages (341 $\neq 4 \mathrm{Ma}$ and $387 \pm$ $2 \mathrm{Ma}$ ) on these volcanics, which indicate that they are both Devonian and mid-Carboniferous.

Volcanic rocks are also present in the Late Devonian-Early Carboniferous Fisset Brook Formation (Kelly and Mackasey 1965, Cormier and Kelley 1964) in Cape Breton Island (Fig. 1). The Fisset Brook Formation (FBF) ranges in thickness from $250 \mathrm{~m}$ to $1,000 \mathrm{~m}$ of which volcanic rocks form the main part. It invariably rests unconformably upon Precambrian basement rocks and generally passes upwards into Early Carboniferous non-marine and marine sedimentary rocks. The FBF rocks are usually steeply dipping due to deformation associated with the Hercynian Orogeny. The samples were collected from the Cheticamp and Lake Ainslie areas and by Smith and Macdonald (1981) from Lowland Cove (LC) at the northern part of Cape Breton Island (Fig. 1). Smith and Macdonald (1981) showed that the section at Lowland Cove consists of a basal porphyritic rhyolite ( $275 \mathrm{~m}$ thick) overlain by interbedded conglomerate, sandstone and siltstone ( $225 \mathrm{~m}$ thick) followed by mafic tuffs and flows $(275 \mathrm{~m}$ thick). Spores in the sedimentary rocks interbedded with the LC volcanic rocks are of Upper Devonian age. They are unconformably overlain by sedimentary rocks of the Horton Group (Smith and Macdonald 1981). The Fisset Brook Formation in the type section (near Cheticamp) and Lake Ainslie was extensively studied by Kelly and MacKasey (1965) and Blanchard (1982). The FBF rhyolites from the latter areas have $\mathrm{Rb} / \mathrm{Sr}$ isochron ages of $376 \pm 12 \mathrm{Ma}$ and $370 \pm 20$ $\mathrm{Ma}$, respectively (Cormier and Kelly 1964, Keppie and Smith 1978).

\section{PETROGRAPHIC NOTES}

The mafic volcanics of the McAras Brook Formation are usually dark greenish gray with amygdules in the upper parts of some flows. The amygdules are mainly filled with calcite or chlorite. Calcite also commonly occurs in the form of fine veins which cut the rocks. The rocks are massive, aphanitic to porphyritic. Their primary mineral assemblage consists of plagioclase and clinopyroxene (augite) phenocrysts set in a finer-grained matrix of plagioclase, clinopyroxene and opaque minerals. $\mathrm{C}$ linopyroxene phenocrysts are more abundant at Ballantynes Cove whereas plagioclase phenocrysts are predominant in basalts from the type section. Microprobe analyses of fresh plagioclase relics from the type section basalts gave compositions usually ranging from An59Ab390r2 to An51Ab470r2. The basalts from both sections have undergone alteration. The plagioclase is commonly saussuritized or albitized and clinopyroxene is replaced by chlorite or actinolite. The variably altered matrix also contains chlorite, calcite and quartz in cracks and small vesicles. In general, the rocks from the type section are more altered and contain fewer fresh relics of clinopyroxene than those from Ballantynes Cove.

The basalts from the Fountain Lake Group and from the Fisset Brook Formation are both composed mainly of clinopyroxene (augite) and plagioclase (andesine-labradorite) with subordinate amounts of $\mathrm{Fe}-\mathrm{Ti}$ oxides. The rocks may contain phenocrysts of plagioclase enclosed in an ophitic matrix. The primary magmatic minerals of the basalts are replaced to a variable degree by secondary phases. The secondary minerals include albite, chlorite, epidote, zeolites, calcite and sericite. Amygdules are abundant particularly at the top of the sections and are filled mainly by chlorite, zeolites and calcite.

The rhyolites of the Fountain Lake Group and Fisset Brook Formation are usually porphyritic with phenocrysts of quartz and alkali feldspar set in a fine-grained matrix of quartz, potash feldspar and plagioclase with minor or accessory amounts of calcite, chlorite, Fe-Ti oxides and Fe-oxides. The petrography of the Fisset Brook Formation has been recently, described by Blan- 
chard (1982) for the Cheticamp-Margaree and Lake Ainslie areas and by Smith and Macdonald (1981) for the Lowland Cove area.

\section{ANALYTICAL NOTES}

The major elements were determined by $X$-ray fluorescence and supplementary techniques. Analyses of $\mathrm{Zr}, \mathrm{Nb}, \mathrm{Y}, \mathrm{Rb}$, $\mathrm{Sr}, \mathrm{Ba}, \mathrm{La}$ and $\mathrm{Ce}$ were also carried out by $X$-ray fluorescence whereas rare-earth elements (REE) were determined by instrumental neutron activation. The precision and accuracy of the trace element data were given by Dostal and Capedri (1979) and "Dupuy et al. (1979). The whole rock analyses selected from a suite of 80 analyzed samples are given in Tables 1 and 2. Analyses of clinopyroxene were done using an energy dispersive microprobe. The average compositions of the clinopyroxenes are given in Table 3. The individual analyses of whole-rocks and clinopyroxenes and locations of the samples are deposited in the Open File Library of the Nova Scotia Department of Mines and Energy. Analyzed whole rock samples include 38 basalts from the McAras Brook Formation (19 from the type section and 19 from Ballantynes Cove), 20 samples from the Fisset Brook Formation ( 7 basalts and 2 rhyolites from Lowland Cove, 9 basalts from the type section and 2 rhyolites from Lake Ainslie), and 7 basalts and 15 rhyolites from the Fountain Lake Group (Fig. 1). Sampling was restricted to these areas because they are the only well dated Devono-Carboniferous volcanic rocks. Other presumed Devono-Carboniferous volcanic rocks were not sampled as their significance to tectonic modelling would be difficult to assess or they are covered by other work (Blanchard 1982).

\section{GEOCHEMISTRY}

The chemical composition of the DevonoCarboniferous volcanic rocks of Nova Scotia confirms the petrographic observations of the predominance of basalts and rhyolites. The volcanic rocks of the McAras Brook Formation from both the type section and Ballantynes Cove are basalts with $\mathrm{SiO}_{2}<55 \%$ (on a volatilefree basis). Volcanic suites from the Fisset Brook Formation and Fountain Lake Group are bimodal with respect to $\mathrm{SiO}_{2}$ and are composed usually of basalts and rhyolites, although the rare occurrence of intermediate rocks has also been reported (e.g. Smith and Macdonald 1981, Blanchard 1982).

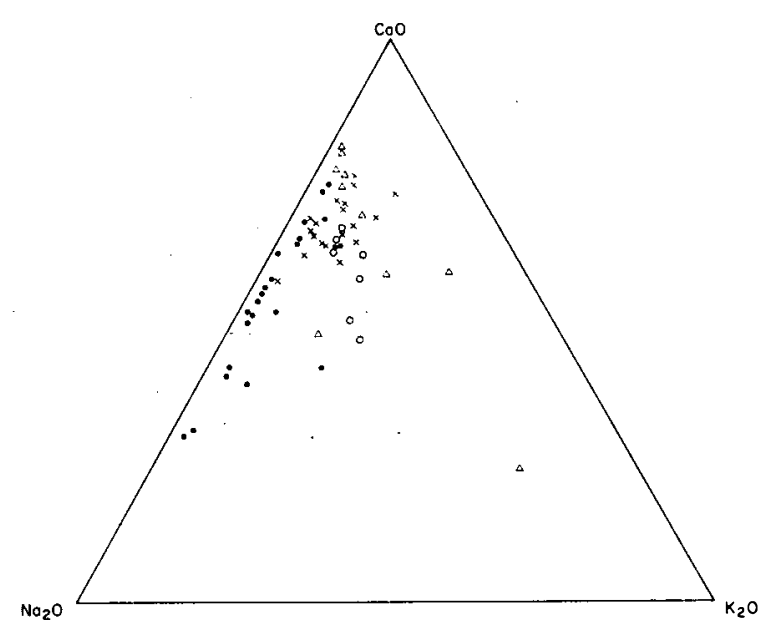

Fig. 2 - $\mathrm{CaO}-\mathrm{K}_{2} \mathrm{O}-\mathrm{Na}_{2} \mathrm{O}$ diagram for some Devono-Carboniferous basalts of Nova Scotia. - type section of McAras Brook Formation; $\quad x$ - Ballantynes Cove, $\Delta-$ Fountain Lake Group, 0 - Lowland Cove.

\section{Alteration}

All the analyzed samples have been affected by secondary processes which modified their chemical composition. The rocks have variable but high $\mathrm{H}_{2} \mathrm{O}$ contents and a low $\mathrm{FeO} / \mathrm{Fe}_{2} \mathrm{O}_{3}$ ratio. In addition, some samples are high in $\mathrm{CO}_{2}$. Among the studied volcanic rocks, the effects of alteration on the chemical compositions are most pronounced in MAB basalts, which have up to $4.3 \%$ of $\mathrm{H}_{2} \mathrm{O}+$. In this section, the variable degree of oxidation is reflected by the wide range of $\mathrm{FeO} / \mathrm{Fe}_{2} \mathrm{O}_{3}$ ratios $(0.07-1.84)$. This ratio is the lowest in the basal flow where it is accompanied by abundant hematite in thin section. The effects of secondary processes are also shown by variations of $\mathrm{Na}_{2} \mathrm{O}, \mathrm{K}_{2} \mathrm{O}$ and $\mathrm{CaO}$ (Fig. 2). On average, the basalts are enriched in $\mathrm{Na}_{2} \mathrm{O}$ and depleted in $\mathrm{CaO}$. The in- 
verse variations of $\mathrm{Na}_{2} \mathrm{O}$ and $\mathrm{CaO}$ which are reflected in thin section by albitization of plagioclase is particularly clearly displayed by MAB rocks.

Internal consistencies and overall systematic variations in basalts from $B C$, LC and FLG show that the composition of these rocks has been less modified during alteration than those from MAB. The composition of the rhyolites also seems to have been affected by secondary processes. However, in spite of alteration, the original geochemical characteristics of the rocks and the magmatic variation trends are still relatively well preserved (Tables 1 and 2).

\section{Basalts}

Major elements.- The mafic rocks have $\mathrm{SiO}_{2}$ contents (on a volatile-free basis) ranging from 47 to $55 \%$ and $\mathrm{FeO}_{\text {tot }} / \mathrm{MgO}$ ratios varying from 0.8 to $>3$. Most analyzed samples from Ballantynes Cove are nepheline normative, however those from the other areas are mainly $01-$ and/or $\mathrm{Hy}$-normative. For a given $\mathrm{FeO}_{\text {tot }}$ Mgo ratio, the basalts of Ballantynes Cove have higher contents of $\mathrm{TiO}_{2}$ and $\mathrm{P}_{2} \mathrm{O}_{5}$ and lower $\mathrm{SiO}_{2}$ and $\mathrm{Al}_{2} \mathrm{O}_{3}$ than those from the other areas. They also have relatively uniform composition with only limited chemical variations $\left(\mathrm{FeO}_{\text {tot }} / \mathrm{MgO}=0.8-1.6\right)$. On the other hand, the basalts from the other localities display a large range of $\mathrm{FeO}_{\text {tot }} /$ $\mathrm{MgO}$ ratios which positively correlate with $\mathrm{TiO}_{2}$ and $\mathrm{P}_{2} \mathrm{O}_{5}$. The increase of $\mathrm{TiO}_{2}$ with the $\mathrm{FeO}_{\text {tot }} / \mathrm{MgO}$ ratio is typical of tholeiitic suites. The presence of rocks with high $\mathrm{TiO}_{2}$ contents and $\mathrm{FeO}_{\text {tot }} / \mathrm{MgO}$ ratios among the tholeiitic basalts indicates that these basaltic suites underwent extensive low-pressure fractional crystallization. Compared to typical calc-alkaline high alumina basalts, the studied basalts are higher in $\mathrm{TiO}_{2}, \mathrm{FeO}_{\text {tot }}$ and $\mathrm{MgO}$ but lower in $\mathrm{SiO}_{2}$.

Trace elements - Since secondary processes frequently affect the distribution of many trace elements most of the following discussion deals with the ele- ments which are generally considered to be rather immobile and the samples selected were the least altered from the collected suites.

The abundances of trace elements corroborate the differences, shown by major elements, in the basalt composition between Ballantynes Cove and the other localities. For a given $\mathrm{FeO}_{\text {tot }}$ / $\mathrm{MgO}$ ratio, the $\mathrm{BC}$ basalts are higher in light REE (LREE), $\mathrm{Zr}$, and $\mathrm{Nb}$. In fact the abundances of these elements in the $\mathrm{BC}$ basalts are characteristic of alkali rocks. Their REE patterns (Fig. 3) are strongly fractionated with LREE enrichment and gradual depletion of heavy REE (HREE). Their $\mathrm{La} / \mathrm{Yb}$ ratio is $\sim 30$ and is also typical of alkali basalts.

The REE patterns of the basalts from the other localities show moderate LREE enrichment and a smaller degree of fractionation (La/Yb 4-10) than the BC rocks. The patterns resemble those of continental tholeiites or tholeiites dredged from the Atlantic Ocean near $43^{\circ} \mathrm{N}$ (Shibata et al. 1979). However the relative enrichment of incompatible elements and the inter-element relationships such as $\mathrm{TiO}_{2}$ vs $\mathrm{Zr}$ (Fig. 4) show that all the Devono-Carboniferous basalts are of the within-plate type, as previously suggested by Keppie and Dostal (1980), and later for FBF basalts by Smith and Macdonald (1981) and B1anchard (1982).

\section{Rhyolites}

On the Ab-Or-Q diagram (Dostal et al. 1983) the scatter of the Devono-Carboniferous silicic rocks is largely due to alteration, although most of them lie within the granitic field of Winkler and Von Platten (1961). Compared to recent rhyolite sequences (Ewart and Stipp 1968, Zielinski et al. 1977, Dostal et al. 1982, Cameron and Hanson 1982), they are lower in $\mathrm{CaO}$ and have a relatively high $\mathrm{K}_{2} \mathrm{O} / \mathrm{Na}_{2} \mathrm{O}$ ratio. The studied rhyolites show large variations in the abundances of lithophile elements. The LC rocks are distinctly higher in LREE, $\mathrm{Zr}$ and $\mathrm{Nb}$ than the other rhyolites. The REE patterns of rhyolites from FLG show 
Table 1

CHEMICAL COMPOSITION OF REPRESENTATIVE SAMPLES FROM THE MCARAS BROOK FORMATION

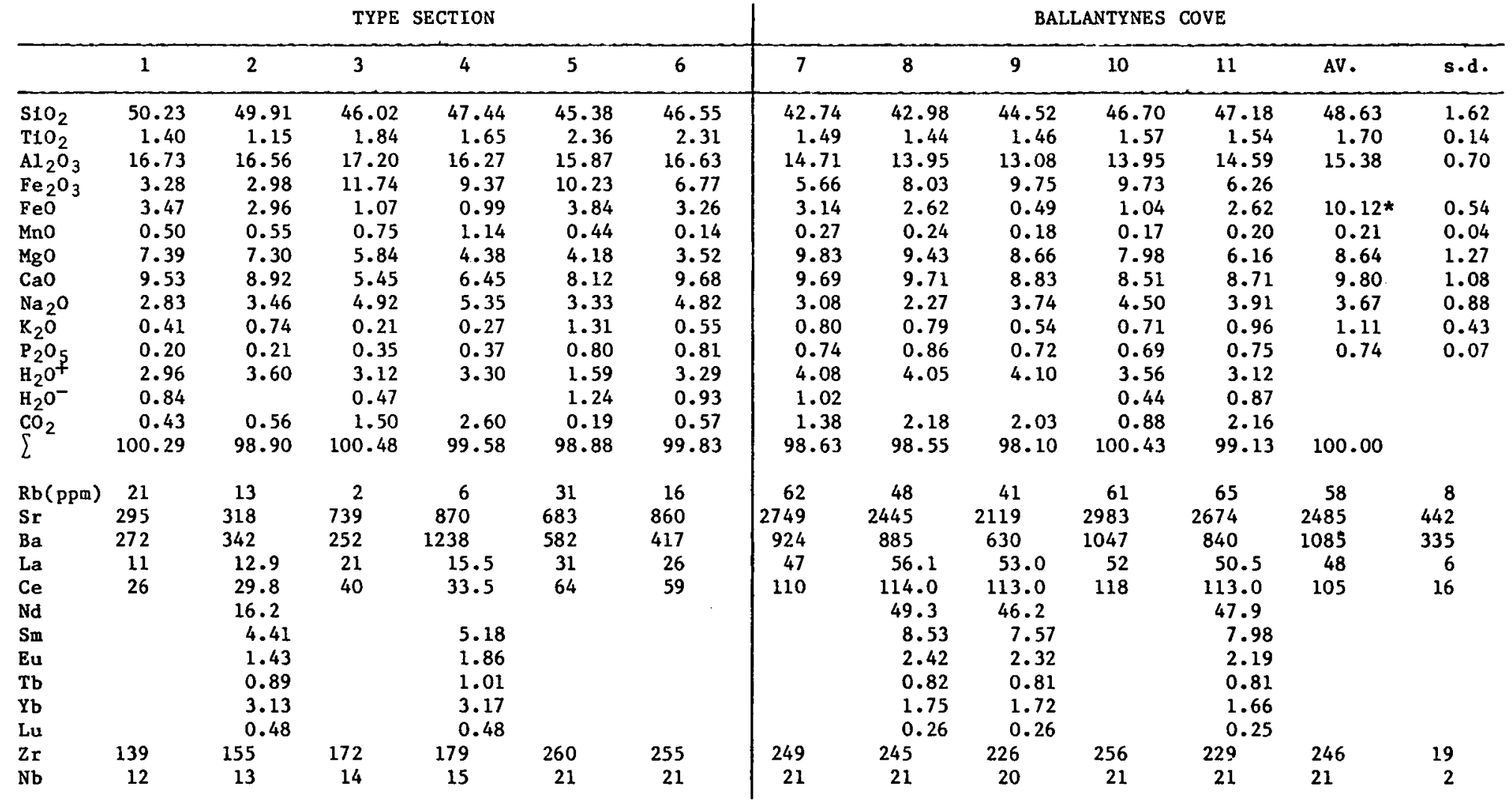



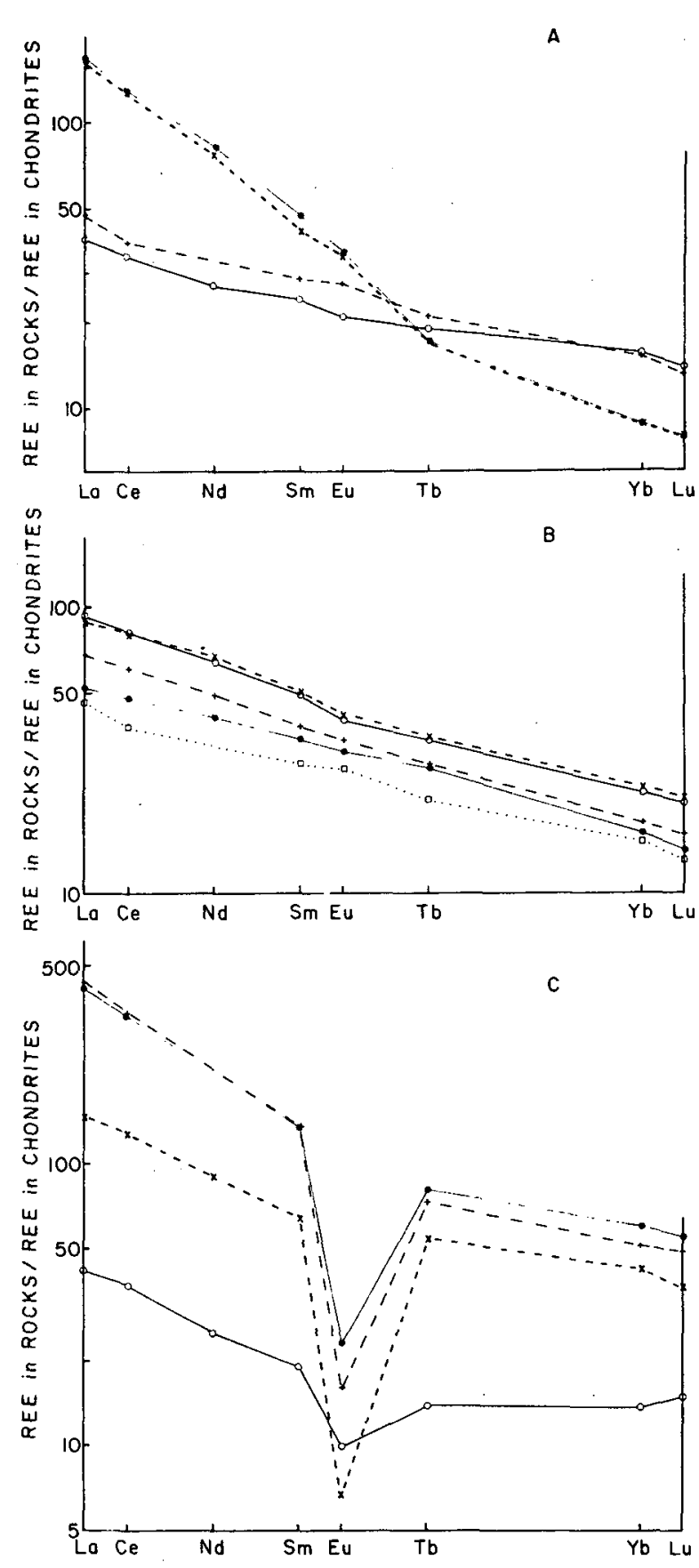

Fig. 3 - A - Chondrite-normalized REE abundances of basalts of McAras Brook Formation from Ballantynes Cove ( $\bullet$ sample 8 and $x$ - sample 9 ) and from the type section ( - sample 4 and 0 - sample 2). B - Chondrite-normalized REE abundances of basalts from the Fisset Brook Formation in Lowland Cove. (o sample 13 and $x$ - sample 14) from the Fountain Lake Group (+ - sample 20 and - - sample 19) and from the McAras Brook
LREE enrichment with a La/Yb ratio of about 5 and a small negative Eu anomaly (Fig. 3). The LC rhyolites have more fractionated REE patterns with a La/Yb ratio $>10$ and a distinct negative Eu anomaly.

\section{Clinopyroxene}

The average compositions of clinopyroxene from $M A B, \quad B C$ and $L C$ basalts are given in Table 3 . The clinopyroxene from the $B C$ rocks are augites with a compositional range of Wo 42.0-47.6 En 38.8-47.4 Fs 9.8-14.0. The relics of clinopyroxene, both phenocrysts and in groundmass also show distinct chemical variations in $\mathrm{Ti}, \mathrm{Al}$ and $\mathrm{Na}$. Titanium displays a positive correlation with the $\mathrm{Fe} / \mathrm{Mg}$ ratio whereas $\mathrm{SiO}_{2}$ correlates negatively with $\mathrm{Al}_{2} \mathrm{O}_{3}$ and $\mathrm{TiO}_{2}$. The rims of some augite crystals are higher in $\mathrm{Ti}, \mathrm{Al}$ and $\mathrm{Fe}$ and lower in $\mathrm{Ca}$ than their cores.

Although clinopyroxene of the MAB basalts is also augite, there are significant differences in the compositions of this mineral from the two sections of the McAras Brook Formation. On the average, clinopyroxenes from $M A B$ basalts are higher in $\mathrm{SiO}_{2}, \mathrm{FeO}_{\text {tot }}$ and $\mathrm{MnO}$ and lower in $\mathrm{Al}_{2} \mathrm{O}_{3}$ and $\mathrm{CaO}$ than those from $\mathrm{BC}$ rocks. They also have a lower $\mathrm{Al}^{\text {iv }}$ and Wo component but a higher Fs component with a composition of Wo 37.442.7 En 39.8-42.8 Fs 14.9-22.1 MAB pyroxenes also do not display covariation of $\mathrm{TiO}_{2}$ vs $\mathrm{FeO}_{\text {tot }} / \mathrm{MgO}$ and of $\mathrm{SiO}_{2}$ vs $\mathrm{TiO}_{2}$. Compared to the average compositions of clinopyroxenes from various rock types, $M A B$ clinopyroxenes have very low abundances of $\mathrm{Al}_{2} \mathrm{O}_{3}$ (Table 3 ). Clinopyroxene from LC basalts are similar to those from $M A B$.

Formation type section (a-sample 4$)$. $C$ - Chondrite-normalized REE abundances of rhyolites from the Fisset Brook Formation in Lowland Cove (+ - sample 16 and - sample 15) and in the Lake Ainslie area (o - sample 17) and from the Fountain Lake Group (x - sample 26). Chondritic values from Frey et al. (1968). 
Table 2

CHEMICAL COMPOSITION OF REPRESENTATIVE VOLCANIC ROCKS FROM THE FISSET BROOK FORMATION AND FOUNTAIN LAKE GROUP

FISSET BROOK FORMATION FOUNTAIN LAKE GROUP

\begin{tabular}{|c|c|c|c|c|c|c|c|c|c|c|c|c|c|c|c|}
\hline & 12 & 13 & 14 & 15 & 16 & 17 & 18 & 19 & 20 & 21 & 22 & 23 & 24 & 25 & 26 \\
\hline $\mathrm{SiO}_{2}$ & 49.70 & 49.10 & 48.70 & 73.50 & 74.90 & 70.79 & 45.80 & 45.70 & 46.55 & 46.13 & 45.80 & 75.44 & 76.41 & 73.35 & 79.56 \\
\hline $\mathrm{T}^{\prime} \mathrm{O}_{2}$ & 1.70 & 2.77 & 2.86 & 0.35 & 0.28 & 0.30 & 1.25 & 2.26 & 2.45 & 2.42 & 3.02 & 0.20 & 0.27 & 0.18 & 0.10 \\
\hline $\mathrm{Al}_{2} \mathrm{O}_{3}$ & 15.90 & 13.50 & 13.60 & 12.40 & 11.70 & 14.24 & 16.20 & 15.61 & 16.14 & 15.50 & 14.80 & 13.57 & 11.05 & 13.63 & 10.73 \\
\hline $\mathrm{Fe}_{2} \mathrm{O}_{3}$ & 5.72 & 8.06 & 9.00 & 2.46 & 2.24 & 0.45 & 6.54 & 8.13 & 9.14 & 5.35 & 6.72 & 1.09 & 2.47 & 0.86 & 0.55 \\
\hline $\mathrm{Fe} 0$ & 5.65 & 6.65 & 5.70 & 1.10 & 0.85 & 1.45 & 2.95 & 4.69 & 4.64 & 7.59 & 8.25 & 1.25 & 1.25 & 0.67 & 0.87 \\
\hline MnO & 0.23 & 0.36 & 0.24 & 0.08 & 0.05 & 0.03 & 0.42 & 0.16 & 0.24 & 0.20 & 0.28 & 0.04 & 0.04 & 0.01 & 0.02 \\
\hline MgO & 5.36 & 5.37 & 4.80 & 0.46 & 0.11 & 0.50 & 8.27 & 6.02 & 4.75 & 5.62 & 5.23 & 1.57 & 0.28 & 0.17 & 0.22 \\
\hline $\mathrm{CaO}$ & 7.69 & 4.98 & 7.56 & 0.59 & 0.63 & 0.14 & 10.90 & 10.13 & 6.78 & 9.13 & 9.48 & 0.27 & 0.45 & 0.21 & 0.35 \\
\hline $\mathrm{Na}_{2} \mathrm{O}$ & 3.42 & 3.16 & 2.92 & 3.21 & 2.03 & 1.57 & 2.47 & 2.48 & 2.48 & 2.61 & 2.73 & 0.00 & 3.42 & 2.15 & 2.72 \\
\hline $\mathrm{K}_{2} \mathrm{O}$ & 1.17 & 1.80 & 1.76 & 4.90 & 6.60 & 10.00 & 0.23 & 0.62 & 2.34 & 1.45 & 0.68 & 4.82 & 4.26 & 7.94 & 4.43 \\
\hline $\mathrm{P}_{2} \mathrm{O}_{5}$ & 0.47 & 0.81 & 0.79 & 0.04 & 0.02 & 0.04 & 0.19 & 0.42 & 0.41 & 0.33 & 0.59 & 0.04 & 0.02 & 0.03 & 0.05 \\
\hline $\mathrm{H}_{2} \mathrm{O}^{+}$ & 2.20 & 3.65 & 2.55 & 0.80 & 0.40 & 0.79 & 3.10 & 3.01 & 2.73 & 2.50 & 2.55 & 1.96 & 0.21 & 0.69 & 0.52 \\
\hline $\mathrm{H}_{2}^{2} \mathrm{O}^{-}$ & & & & 0.00 & 0.02 & & 0.65 & & & & 0.00 & & & & \\
\hline $\mathrm{CO}_{2}$ & 0.05 & 0.10 & 0.10 & 0.20 & 0.35 & 0.17 & 0.80 & 0.70 & 0.48 & 0.85 & 0.05 & 0.46 & 0.26 & 0.00 & 0.27 \\
\hline$\Sigma$ & 99.26 & 100.31 & 100.58 & 100.09 & 100.18 & 100.47 & 99.77 & 99.93 & 99.13 & 99.68 & 100.18 & 100.71 & 100.39 & 99.89 & 100.38 \\
\hline $\mathrm{Rb}(\mathrm{ppm})$ & 37 & 46 & 38 & 115 & 124 & 240 & 12 & 24 & 74 & 55 & 19 & 201 & 168 & 202 & 120 \\
\hline Sr & 306 & 202 & 309 & 54 & 70 & 103 & 323 & 285 & 305 & 386 & 259 & 30 & 80 & 167 & 138 \\
\hline $\mathrm{Ba}$ & 342 & 519 & 584 & 267 & 297 & 1459 & 190 & 205 & 604 & 408. & 207 & 865 & 86 & 536 & 435 \\
\hline La & 20 & 30.8 & 29.1 & 138 & 144 & 13.8 & 7 & 17.1 & 22.5 & 18 & 22 & 37 & 99 & 32 & 47.4 \\
\hline $\mathrm{Ce}$ & 48 & 71.6 & 71.3 & 291 & 293 & 33.1 & 16 & 42.5 & 54.0 & 46 & 53 & 84 & 237 & 69 & 113 \\
\hline Nd & & 38.5 & 40.3 & & & 15.2 & & 24.5 & 29.4 & & & & & & 52.3 \\
\hline $\mathrm{Sm}$ & & 8.92 & 9.01 & 24.1 & 23.8 & 3.37 & & 6.17 & 6.84 & & & & & & 11.4 \\
\hline Eu & & 2.77 & 2.93 & 1.61 & 1.09 & 0.68 & & 2.24 & 2.34 & & & & & & 0.46 \\
\hline $\mathbf{T b}$ & & 1.58 & 1.67 & 3.76 & 3.45 & 0.65 & & 1.26 & 1.31 & & & & & & 2.55 \\
\hline $\mathrm{Yb}$ & & 4.55 & 4.67 & 11.8 & 10.6 & 2.77 & & 3.22 & 3.48 & & & & & & 8.43 \\
\hline Lus & & 0.70 & 0.73 & 1.89 & 1.68 & 0.52 & & 0.48 & 0.54 & & & & & & 1.23 \\
\hline $\mathrm{Zr}$ & 203 & 278 & 271 & 761 & 689 & 211 & 100 & 225 & 248 & 186 & 253 & 171 & 1264 & 216 & 214 \\
\hline $\mathrm{Nb}$ & 17 & 22 & 22 & 37 & 33 & 16 & 9 & 19 & 21 & 16 & 22 & & & & \\
\hline
\end{tabular}

FISSET BROOK FORMATION: Lowland Cove: samples 12-16 (major elements taken from Smith and Macdonald, 1981); Lake Ainslie: sample 17. FOUNTAIN LAKE GROUP: Devonian: samples 18-24, Carboniferous: 25-26. 
Compositions of clinopyroxene relics in the basalts confirm their whole-rock geochemical characteristics and the inferred paleotectonic settings of the host lavas. On the $\mathrm{SiO}_{2}$ vs $\mathrm{Al}_{2} \mathrm{O}_{3}$ diagram (Fig. 5), the pyroxenes from $M A B$ and LC volcanics fall into the subalkaline field of Le Bas (1962) whereas those from $B C$ basalts plot predominantly into the alkaline field. On the discriminant diagrams of Leterrier et al. (1982) the pyroxenes from MAB and LC are characteristic of non-orogenic tholeiitic basalts whereas clinopyroxenes from $B C$ seem to be mainly related to alkaline series.

\section{PETROGENESIS}

With the exception of rocks from Ballantynes Cove, the analyzed DevonoCarboniferous basalts are continental tholeiites. The metavolcanics from Ballantynes Cove, which have higher contents of relatively immobile lithophile elements (such as LREE, $\mathrm{Zr}, \mathrm{Nb}$ ) for a comparable $\mathrm{FeO}_{\text {tot }} / \mathrm{MgO}$ ratio, resemble alkali basalts. The basalts underwent variable degrees of low-pressure fractional crystallization which changed the abundances of many elements. However, some element ratios including $\mathrm{Ti} / \mathrm{Zr}$,
$\mathrm{Zr} / \mathrm{Nb}$ and the shape of the REE patterns change little during such a process and thus they are suitable for evaluating the origin of these rocks, particularly as these elements probably were not affected by secondary processes. Similarities of element ratios such as $\mathrm{Zr} / \mathrm{Nb}$ among the analyzed basalts suggest a genetic relation between the tholeiitic and alkali basalts, in particular, their derivation from a similar source. Kay and Gast (1973) and Frey et al. (1978) have shown that alkali basalts, with highly fractionated REE patterns such as those of the BC basalts can be generated by a small degree of partial melting of upper mantle garnet peridotite with chondritic-relative REE abundances. The model calculations suggest that this mechanism can also produce liquids with the geochemical characteristics of the parental magmas of metabasalts from Ballantynes Cove. Subsequent low-pressure fractional crystallization of such magmas can form melts with the compositions of the BC rocks.

Compared to the $\mathrm{BC}$ alkali basalts, the other continental tholeiitic basalts have lower LREE but higher HREE abundances. These rocks could be derived from a similar parental source as the
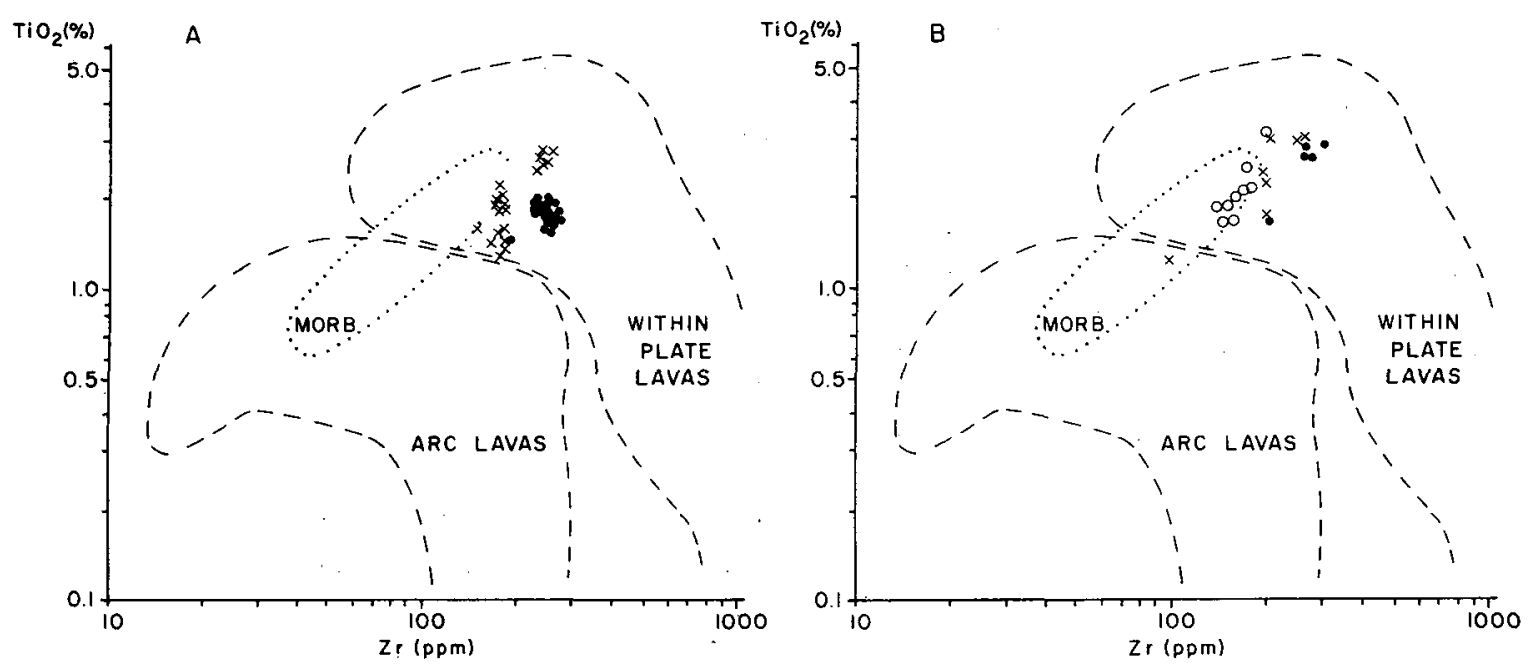

Fig. 4 - A - $\mathrm{TiO}_{2}-\mathrm{Zr}$ diagram of Pearce et al. (1981) for the basalts of the McAras Brook Formation (o-Ballantynes Cove; $x$ - type section). B $\mathrm{TiO}_{2}-\mathrm{Zr}$ diagram of Pearce et al. (1981) for the basalts from the Foun tain Lake Group $(x)$ and the Fisset Brook Formation at Lowland Cove (•) and the type section and Lake Ainslie ( 0 ). 

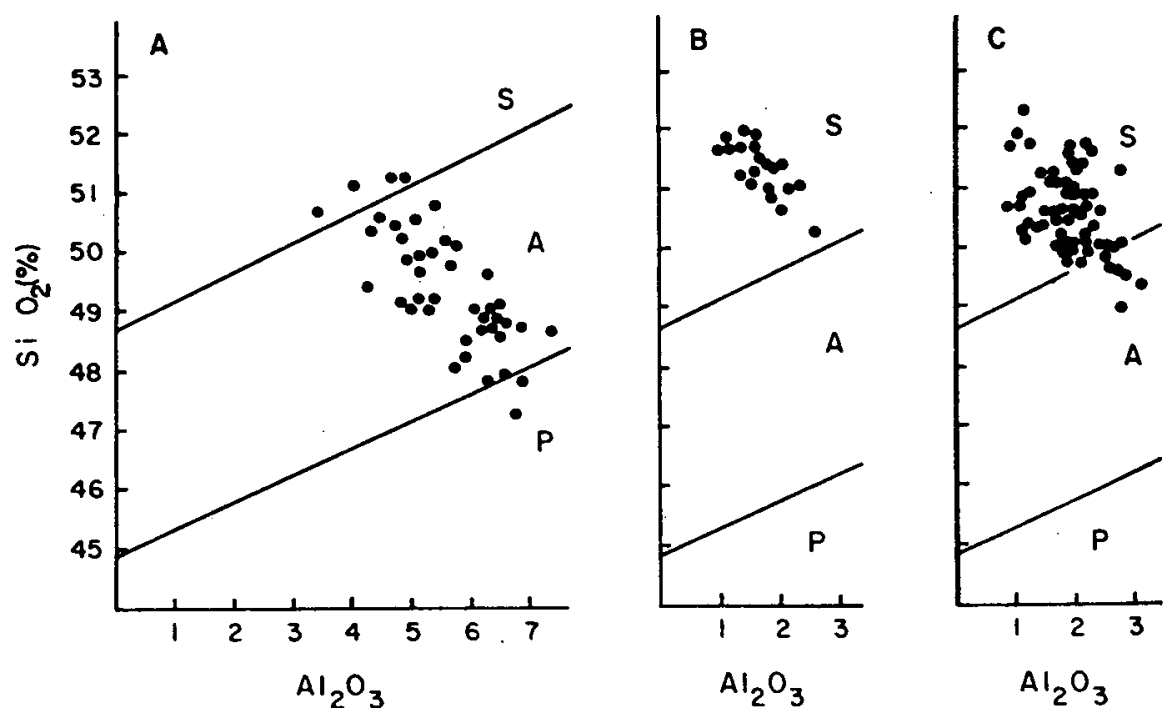

Fig. 5 - Variations of $\mathrm{SiO}_{2}$ vs $\mathrm{Al}_{2} \mathrm{O}_{3}$ in clinopyroxenes from the basalts of A-Ballantynes Cove, B-type section of the McAras Brook Formation and C-Fisset Brook Formation at Lowland Cove. Fields of pyroxenes from: SSubalkaline rocks, A-Alkaline rocks, and P-Peralkaline rocks (after LeBas 1962).

alkali basalts but such a process would involve a significantly higher degree of partial melting of upper mantle peridotite containing a phase that preferentially enriches HREE, for example, garnet. In fact, the process involving variable degrees of partial melting of garnet-bearing upper mantle has been frequently invoked to elucidate the genetic relation between associated alkali and tholeiitic basalts (e.g. Frey et al. 1974, Shibata et al. 1979).

The two most frequently invoked processes for the genesis of rhyolitic rocks are fractional crystallization of basaltic or andesitic magma and partial melting of crustal rocks (Ewart and Stipp 1968). In the Devono-Carboniferous volcanic rocks there is some evidence that rhyolites might have been produced by differentiation of a basic magma (e. g. high contents of some incompatible elements in LC rhyolites accompanied by a distinct negative Eu anomaly in their REE pattern). However, the lack of intermediate rocks argues against this model. In fact, as recently demonstrated by Cameron and Hanson (1982) it is difficult, on the basis of geochemistry alone, to discriminate between these two processes. The close spatial and temporal associations of rhyolites and basalts suggest that these rocks are genetically related. However, the overall chemical similarity of the felsic rocks to recent calc-alkali rhyolites suggest that a more plausable mechanism for their origin is by partial melting of the crustal rocks. This process may also account for diversity in the composition of rhyolites from different areas and the lack of intermediate rocks. The crustal anatexis was probably related to the ascending basaltic magma.

\section{CONCLUSION}

The geochemical results presented here are consistent with the geological interpretation of these volcanic rocks as part of Devono-Carboniferous intraplate continental molasse deposits (Keppie and Dostal 1980) formed during the transpression stage of the Acadian Orogeny (Keppie 1982a) in an intramontane or pull-apart basin centered about the Magdalen Islands (Keppie 1982b). The development of the Magdalen pullapart basin immediately post-dated the compressive phase of the Acadian Orogeny 
Table 3

AVERAGE COMPOSITION OF CLINOPYROXENES

\begin{tabular}{lccccccccc} 
& \multicolumn{1}{c}{$\mathrm{BC}$} & \multicolumn{1}{c}{$\mathrm{MAB}$} & \multicolumn{2}{c}{$\mathrm{LC}$} & \multicolumn{2}{c}{ WPT } & \multicolumn{2}{c}{ WPA } & \multicolumn{2}{c}{ VAB } \\
$\mathrm{SiO}_{2}$ & $49.39(1.01)$ & $51.36(0.45)$ & $50.60(0.70)$ & 51.4 & $(1.1)$ & 49.2 & $(2.4)$ & 50.7 & $(1.5)$ \\
$\mathrm{THO}_{2}$ & $1.02(0.30)$ & $1.16(0.21)$ & $1.36(0.28)$ & $0.94(0.46)$ & $1.77(1.20)$ & $0.67(0.37)$ \\
$\mathrm{Al}_{2} \mathrm{O}_{3}$ & $5.62(0.89)$ & $1.75(0.42)$ & $1.90(0.52)$ & 3.2 & $(1.4)$ & 4.1 & $(2.7)$ & 3.3 & $(1.8)$ \\
$\mathrm{FeO}^{*}$ & $7.16(0.60)$ & $10.81(1.22)$ & $11.96(1.31)$ & 11.5 & $(3.5)$ & 11.3 & $(5.5)$ & 9.1 & $(4.5)$ \\
$\mathrm{MnO}$ & $0.15(0.06)$ & $0.30(0.10)$ & $0.30(0.08)$ & $0.42(0.40)$ & $0.43(0.38)$ & $0.26(0.15)$ \\
$\mathrm{MgO}$ & $14.46(0.80)$ & $14.46(0.39)$ & $14.13(0.74)$ & 14.8 & $(3.1)$ & 10.9 & $(3.8)$ & 15.3 & $(1.4)$ \\
$\mathrm{CaO}$ & $21.21(0.86)$ & $19.71(0.79)$ & $19.49(0.59)$ & 17.1 & $(3.5)$ & 20.5 & $(2.8)$ & 19.8 & $(3.2)$ \\
$\mathrm{Na}_{2} \mathrm{O}$ & $0.34(0.11)$ & $0.36(0.11)$ & $0.24(0.10)$ & $0.47(0.19)$ & $1.17(1.36)$ & $0.35(0.17)$ \\
$\mathrm{n}$ & 42 & 20 & 70 & & 26 & 82 & 73
\end{tabular}

BC - pyroxenes from basalts of Ballantynes Cove; MAB - pyroxenes from basalts of McAras Brook type section; LC - pyroxenes from basalts of Lowland Cove; WPT - pyroxenes from within-plate tholeiltes (Nisbet and Pearce, 1977); WPA - pyroxenes from within-plate alkalic basalts (N1sbet and Pearce, 1977); VAB - volcanic arc basalts (Nisbet and Perce, 1977). Standard deviations are given in parenthesis; $\mathrm{FeO}^{*}=$ total $\mathrm{Fe}$ recalculated as $\mathrm{FeO} ; \mathrm{n}=$ number of analyses.

which produced folds and an attendant cleavage in Emsian and older rocks. It was accompanied by rifting that led to extensive volcanism along the faults bounding the basin. The Devono-Carboniferous volcanic rocks were emplaced mainly around the southern and eastern margins of the basins. Active rifting appears to have occurred in three main pulses: Middle Devonian, Tournaisian (straddling the Devono-Carboniferous boundary) and mid-Carboniferous and were separated by periods of passive sedimentation. In the Cobequid Highlands, some of the volcanism appears to be spatially and temporally related to plutonism, as both yield similar 330$340 \mathrm{Ma} \mathrm{Rb} / \mathrm{Sr}$ whole-rock isochron ages and are juxtaposed (Donohoe and Wallace 1982, Cormier 1982). This geological setting is very similar to the Mount Pleasant area in southern New Brunswick suggesting interesting economic possibilities.

\section{ACKNOWLEDGEMENTS}

The study was supported by grants from NSERC Canada (operating grant A3782) the Faculty of Science of Saint Mary's
University, and the Mineral Resources Division of Nova Scotia Department of Mines and Energy. The authors thank Dr. D. B. Clarke for permitting access to microprobe facilities at Dalhousie University and Dr. A.S. Macdonald and P.K. Smith for allowing use of their samples for further analysis. We would also like to thank Drs. J.B. Murphy, R.P. Raeside and S.M. Barr for critical comments.

BELL, W.A. 1926. Carboniferous formations of Northumberland Strait, Nova Scotia. Geological Survey of Canada, Summary Report 1924, part C, pp. 142180 .

BLANCHARD, M.C. 1982. Geochemistry and petrology of the Fisset Brook Formation, Western Cape Breton Island, Nova Scotia. M.Sc. thesis, Dalhousie University, 198p.

BOUCOT, A.J., DEWEY, J.F., DINELEY, D. L., FLETCHER, R., FYSON, W.K., GRIFFIN, J.G., HICKOX, C.F., MCKERROW, W.S. and ZIEGLER, A.M. 1974. Geology of the Arisaig area Antigonish County, Nova Scotia. Geological Society of America, Special Paper 139, 191p. 
CAMERON, K.L. and HANSON, G.N. 1982. Rare earth element evidence concerning the origin of voluminous mid-Tertiary rhyolitic ignimbrites and related volcanic rocks, Sierra Madre Occidental, Chihuahua, Mexico. Geochimica et Cosmochimica Acta, 46, pp. 1489-1503.

CORMIER, R.F. 1982. $\mathrm{Rb} / \mathrm{Sr}$ age data for the Fountain Lake Group volcanics. Nova Scotla Department of Mines and Energy. Reports of Activities 1981, p. 14.

CORMIER, R.F. and KELLY, A.M. 1964. Absolute age of the Fisset Brook Formation and the Devonian-Mississippian boundary, Cape Breton Island, Nova Scotia. Canadian Journal of Earth Sciences, 1, pp. 159-166.

DONOHOE, H.V. Jr. and WALLACE, P.I. 1980. Structure and stratigraphy of the Cobequid Highlands, Nova Scotia. Geological Association of Canada, Halifax 80; Field Trip 19, 64p.

DONOHOE, H.V. Jr. and WALLACE, P. I. 1982. Geological Maps of the Cobequid Highlands. Nova Scotia Department of Mines and Energy, Maps 82-6, 7, 8, 9. Scale 1:50,000.

DOSTAL, J. and CAPEDRI, S. 1979. Rareearth elements in high-grade metamorphic rocks from the western Alps. Lithos, 12, pp. 41-49.

DOSTAL, J., COULON, C. and DUPUY, C. 1982. Cainozoic andesitic rocks of Sardinia (Italy). In Thorpe, R.S. (Editor). Andesites: Orogenic Andesites and Related Rocks. John Wylie and Sons, pp. 353-370.

DOSTAL, J., DUPUY, C. and KEPPIE, J.D. 1983. Uranium and thorium in Paleozoic rhyolites of Nova Scotia. Canadian Journal of Earth Sciences, 20, pp. 266-274.

DUPUY, C., DOSTAL, J. and COULON, C. 1979. Geochemistry and origin of andesitic rocks from North-Western Sardinia. Journal of Volcanology and Geothermal Research, 6, pp. 375-389.
EWART, A. and STIPP, J.J. 1968. Petrogenesis of the volcanic rocks of the central North Island, New Zealand as indicated by a study of ${ }^{87} \mathrm{Sr} /{ }^{86} \mathrm{Sr}$ ratios, and $S r, R b, K, V$ and $T h$ abundances. Geochimica et Cosmochimica Acta, 32, pp. 699-735.

FREY, F.A., HASKIN, M.A., POETZ, J. and HASKIN, L.A. 1968. Rare earth abundances in some basic rocks. Journal of Geophysical Research, 73, pp. 6085-6098.

FREY, F.A., BRYAN, W.B. and THOMPSON, G. 1974. Atlantic Ocean floor: Geochemistry and petrology of basalts from Legs 2 and 3 of the Deep-Sea Drilling Project. Journal of Geophysical Research, 79, pp. 5507-5527.

FREY, F.A., GREEN, D.H. and ROYS, D. 1978. Integrated models of basalt petrogenesis: A study of quartz tholeiites to olivine melilitites from South Eastern Australia utilizing geochemical and experimental petrological data. Journal of Petrology, 19, pp. 463-513.

KAY, R., and GAST, P.W. 1973. The rareearth content and origin of alkalirich basalt. Journal of Geology, 81, pp. 653-682.

KELLEY, D.G. and MACKASEY, W.O. 1965. Basal Mississippian volcanic rocks in Cape Breton Island, N.S. Geological Survey of Canada Paper 64-34, 10p.

KEPPIE, J.D. 1982a. Tectonic map of Nova Scotia. Nova Scotia Department of Mines and Energy. Scale 1:500,000.

KEPPIE, J.D. 1982b. The Minas Geofracture. In St. Julien, P. and Beland, J. (Editors). Geological Association of Canada Special Paper 24, pp. 263-280.

KEPPIE, J.D. and SMITH, P.K. 1978. Compilation of isotopic age data of Nova Scotia. Nova Scotia Department of Mines Report 78-4.

KEPPIE, J.D., GILES, P.S. and BOEHNER, R.S. 1978. Some Middle Devonian to Lower Carboniferous rocks of Cape George, Nova Scotia. Nova Scotia Department of Mines, Paper 78-4, 37p. 
KEPPIE, J.D. and DOSTAL, J. 1980. Paleozoic volcanic rocks of Nova Scotia. In Wones, R. (Editor). Caledonides in the U.S.A. International Geological Correlation Program, 27(a), pp. 249256.

LE BAS, M.J. 1962. The role of aluminium in igneous clinopyroxenes with relation to their parentage. American Journal of Science, 260, pp. 267-288.

LETERRIER, J., MAURY, R.C., THONON, P., GIRARD, D. and MARCHAL, M. 1982. Clinopyroxene composition as a method of identification of the magmatic affinitives of paleovolcanic series. Earth and Planetary Science Letters, 59, pp. 138-154.

NISBET, E.G. and PEARCE, J.A. 1977. Clinopyroxene composition in mafic lavas from different tectonic settings. Contributions to Mineralogy and Petrology, 63, pp. 149-160.

OSBERG, P. 1978. Synthesis of the geology of the north-eastern Appalachians (U.S.A.). Geological Survey of Canada Paper 78-13, 27p.

PEARCE, J.A., ALABASTER, T., SHELTON, A.W. and SEARLE, M.P. 1981. The Oman ophiolite as a Cretaceous arc-basin complex: evidence and implications. Philosophical Transactions, Royal Society A300, pp. 299-317.
RUITENBERG, A.A., FYFFE, L.R., McCUTCHEON, S.R., ST. PETER, C.R., D'ARINKI, R.R. and VENUGOPAL, D.V. 1977. Evolution of Pre-Carboniferous tectonstratigraphic zones in the New Brunswick Appalachians. Geoscience Canada, 4, pp. 171-181.

SHIBATA, T., THOMPSON, G. and FREY, F.A. 1979. Tholeiftic and alkali basalts from the Mid-Atlantic ridge at $43^{\circ} \mathrm{N}$. Contributions to Mineralogy and Petrology, 70, pp. 127-142.

SMITH, P.K. and MacDONALD, A.S. 1981. The Fisset Brook Formation at Lowland Cove, Inverness County, Nova Scotia. Nova Scotia Department of Mines and Energy Paper 81-1, 18p.

WILLIAMS, M.Y. 1914. Arisaig-Antigonish District, Nova Scotia. Geological Survey of Canada, Memoir 60, 173p.

WINKLER, H.G.F. and VON PLATEN, H. 1961. Experimentelle Gesteinsmetamorphose. V. Experimentelle anatektischer Schmelzen und ihre petrogenetische Bedeutung. Geochimica et Cosmochimica Acta, 24, pp. 250-259.

ZIELINSKI, R.A., LIPMAN, P.W. and MILLARD, H.T. 1977. Minor element abundances in obsidian, perlite and felsite of calc-alkalic rhyolites. American Mineralogist, 62, pp. 426-437. 